\title{
Religion og sekularisme under covid-19
}

I begyndelsen af 2020 var Kina epicenteret for covid-19, hvorfra virussen hurtigt spredte sig til resten af verden. Pandemien kom som et chok for de uforberedte stater og for deres befolkninger, der hurtigt måtte se deres hverdag underlagt restriktioner i vari erende grad. På den ene side blev sundhedsmyndighedernes udstukne retningslinjer mødt med velvilje og samarbejde, og på den anden side opstod der hurtigt uenigheder både internt $i$ mellem og på tværs af borgere, interessegrupper og politiske partier. Man så også, jo længere krisen trak ud, i stigende grad voldelige sammenstød mellem grupper af borgere og myndigheder. I første fase var nogle staters reaktion at afvise virussens tilstedeværelse i deres lande. Andre var langsomme med at få igangsat initiativer, der kunne reducere smitten, mens enkelte lande til gengæld hurtigt indførte forholdsregler i forsøget på at forhindre et større udbrud.

Online- og offline-information og misinformation har været en del af forskellige grupperingers kamp mod pandemien. Pandemien har ført til analyser, diskussioner og restriktioner både på makro- og mikroniveau, hvor ikke blot politikere, økonomer

Ehab Galal, lektor, ph.d . i Medier og Moderne Samfund i Mellemøsten. Galal forsker i medier i Mellemøsten, aktuelt og historisk, med en særlig interesse i mediernes regionale og globale indflydelse. Han har således undersøgt, hvordan den muslimske og mellemøstlige befolknings brug af medier påvirker deres forståelse af religion og religiøs praksis. I bogen Arab TV-Audiences analyserer han publikums respons på islamisk TV i både Europa og Mellemøsten. Aktuelt arbejder han på et projekt om mellemøstlige oppositionsmedier i og uden for Mellemøsten efter Det Arabiske Forår i 2011. Han er leder af forskningsprojektet Mediatized diaspora (MEDIASP) - Contentious politics among Arab media users in Europe, som er finansieret af Danmarks Frie Forskningsfond nr. 8018-00038B. 
og eksperter, men også religiøse lærde og autoriteter fra verdens religioner har deltaget aktivt. Da restriktionerne ramte hele samfundet, ramte de også den religiøse praksis, blandt andet i form af periodevise nedlukninger af kirker, moskeer og syna goger. At religion således blev et aspekt og et redskab i håndte ringen af covid-19 har samtidig været med til at synliggøre de religiøse institutioner som en del af samfundet. For eksempel blev spørgsmålet som kirkernes tilgængelighed under religiøse højtider en hidtil uset del af den offentlige debat i Danmark.

De offentlige debatter har inddraget mange aspekter såsom retten til religion eller religionsfrihed, det religiøse fællesskab som trøstende og støttende i krisetid, samarbejde versus kon flikt mellem stat og religiøse institutioner, sekulære versus religiøse argumenter for håndtering af sygdom, religionens særlige, helbredende kraft osv. På den måde har religiøse autoriteter verden over spillet en rolle i håndteringen af pandemien enten ved at opfordre medlemmer til at overholde eller ignorere de af staterne udstukne rammer eller ved at forsøge af skabe eksistentiel og religiøs mening ud af den meningsløshed, som pandemien ligesom andre kriser også bragte med sig.

Spørgsmålet om religionens rolle under covid-19 er afsættet for dette nummers ni artikler. Artiklerne giver udvalgte eksempler på, hvordan religiøse lærde fra de tre abrahamitiske religioner, jødedom, kristendom og islam, fortolker pandemien. Fem artikler omhandler islam og de muslimske religiøse lærdes håndtering af pandemien gennem brugen af medier, to artikler omhandler kristendom, og to artikler omhandler jødedom. Eksemplerne stammer fra så forskellige steder som Danmark, Sverige, Tyskland, Italien, Rusland, Israel, Indien, Pakistan, USA og de arabiske lande. Artiklerne bidrager dermed med perspektiver på, hvordan stater og trossamfund verden over har forholdt sig til og prøvet at styre koblingen af religiøse og sundhedsvidenskabelige problemstillinger. De ni artikler viser, hvordan staterne er fælles om deres forsøg på at kontrollere pandemien ved hjælp af videnskabelige og sekulære argumenter, ligesom de forsøger at kontrollere informationer for at modvirke spredningen af misinformation. Staterne har skullet håndtere en situation, hvor religiøse grupperinger, lærde og prædikanter de se neste årtier i kraft af ny teknologi har fået nye platforme for formidling af deres budskaber. Det gælder både etablerede og selvbestaltede religiøse lærde og autoriteter. Resultatet er et nyt medie- og religionslandskab, der er langt vanskeligere at kon- 
trollere, og dermed kommer medierne også til at spille en central rolle for håndteringen af covid-19.

På tværs af de ni artikler finder man en række gennemgående temaer, der belyser trossamfunds og de religiøse autoriteters rolle i forskellige verdensdele i forbindelse med covid-19. Mens artiklernes fokus varierer, træder tre temaer frem som centrale. Det første tema er samspillet mellem stat og trossamfund; det andet er spørgsmålet om, hvordan man som troende kan praktisere sin tro med dens ritualer på trods af restriktioner; og det tredje er, hvorvidt og hvordan covid-19 har forandret samspillet mellem sekularisme og religion.

\section{Staten og religionen}

Helt overordnet viser bidragene til dette særnummer, at trossamfund overvejende har accepteret, fulgt og anbefalet de retningslinjer og restriktioner, som staterne har udstukket. Det betyder dog ikke, at forholdet mellem religion og stat er forblevet uberørt af covid-19. Pandemien både tydeliggør og forandrer allerede eksisterende relationer.

Italien blev hurtigt kendt for at være et af de hårdest ramte lande. I artiklen "Home prayer, unattended funerals and social responsibility: Muslims in Italy and the coronavirus outbreak" skriver Alessandro Gori, som er lektor i arabisk sprog og litteratur ved Københavns Universitet, om muslimske reaktioner på denne nationale krise. Gori belyser, hvordan muslimske paraplyorganisationer i Italien ikke blot støttede op om statens håndtering, men også igangsatte eller deltog i kollektive initiativer, som havde til formål at skabe national solidaritet og fællesskab. Det var alt fra at deltage i fælles interreligiøs bøn for nationen til at opfordre muslimer til at donere blod. Således blev pandemien en anledning til, at muslimske organisationer indgik i dialog og kontakt med det italienske samfund på nye måder og dermed en mulighed for at omforme den islamiske identitet $\mathrm{i}$ Italien og indlejre den i en bredere italiensk ramme.

I andre nationale kontekster har pandemien først og fremmest bekræftet det strategiske allianceforhold mellem religion eller dele af det religiøse establishment og staten. I artiklen "Med bønnens kraft: Et islamisk og kristent arabisk perspektiv på covid-19" viser Ehab Galal, som er lektor i mellemøstlige studier på Københavns Universitet, hvordan religiøse argumenter bru- 
ges til både at bakke op om og udfordre statens håndtering af covid-19. Mens de statsloyale religiøse lærde i de arabiske lande forbliver loyale og ikke blot bakker op om, men legitimerer statens håndtering af covid-19 med islam, forbliver de islamiske lærde, der i forvejen er kritiske over for de arabiske staters politik, kritiske og mistænksomme over for statens motiver for håndteringen af covid-19. I de arabiske lande udspringer håndteringen af religiøs praksis under covid-19 således af allerede etablerede relationer mellem stat og religion, ligesom staterne bruger de statsloyale religiøse autoriteter til at legitimere egen håndtering.

Statens etablerede måder at organisere religion på bliver derfor også afgørende for, hvordan forholdet mellem stat og religion udfoldes under covid-19. Det fremgår ligeledes af artiklen "Islamic Responses to the Covid-19 pandemic in India and $\mathrm{Pa}-$ kistan", der er skrevet af Martin Thomas Riexinger, der er lektor i arabisk og islamstudier ved Aarhus Universitet. Netop sammenligningen mellem Indien og Pakistan synliggør på den ene side, hvilke rolle organiseringen af religion får for statens mulighed for at blande sig i trossamfunds anliggender. I Pakistan er religiøse organisationer autonome, hvilket har betydet, at regeringen ikke kunne gennemtvinge en nedlukning af moskeerne. Derfor forblev de sunnitiske moskeer åbne. På den anden side viser sammenligningen, at når et trossamfund indtager en minoritetsposition, påvirker dette også reaktionen på statens politik. Både de muslimske organisationer i Indien og shiamuslimerne i Pakistan forsøgte ved at følge staternes anbefalinger at leve op til rollen som det "ansvarlige mindretal".

En anden måde at forhandle sin minoritetsposition under covid-19 finder man i artiklen "'Perhaps we see it in negative terms, but, ultimately, it is positive': the responses of Swedish Salafis to Covid-19", som er skrevet af Simon Sorgenfrei. Sorgenfrei er lektor i religionsstudier ved Södertörn Universitet i Stockholm og undersøger, hvordan en af Sveriges mest aktive salafistiske grupper, Islam.nu - også omtalt som Järva-salafister - har reageret på covid-19. En af reaktionerne er, hvad Sorgenfrei kalder retorisk. Det er en form for respons, der er kendetegnet ved at bruge nyheder om pandemien til blandt andet at kritisere den eksisterende politik i forhold til muslimer og migranter, ikke mindst igennem brugen af ironi. Således ironiserer en af gruppens ledere over, at man nu ikke længere må hilse på hinanden med et håndtryk, mens muslimer ellers er blevet kritise- 
ret for ikke at ville give hånd til det modsatte køn. Selv om gruppen dermed forholder sig kritisk til blandt andet staten, viser Sorgenfrei, at det dog ikke er statens håndtering af covid-19, der kritiseres. Denne fremstilles i stedet som i overensstemmelse med islam.

Covid-19 har således synliggjort forholdet mellem stat og religion på flere måder. Mens pandemien har fremmet solidaritet på tværs af trossamfund og samfundsgrupper med minoriteten som aktiv medspiller, har den også cementeret på forhånd etablerede magtrelationer.

\section{Ritualer og den religiøse praksis}

Det var ikke kun i Italien, at interreligiøs bøn blev set som et fællesskabsskabende initiativ. I april 2020 kunne man i flere lande se, hvordan forskellige trossamfund bad for nationen og resten af verden. Således kaldte muslimer i et hidtil uhørt omfang til fælles bøn med et budskab om solidaritet og sammenhold fra minerater i lande som Tyskland, Holland, Storbritannien, Spanien og Belgien, ligesom flere statsledere mødtes med religiøse ledere for sammen at bede Gud om at redde verden fra epidemien. Pandemien har på den måde medvirket til at sætte fokus på den rituelle praksis. Hvor den interreligiøse bøn er en måde at skabe globalt og nationalt fællesskab og solidaritet, hand-ler den rituelle praksis dog også om den enkeltes frihed til at tro og praktisere sin religion. En tro og rituel praksis, som risikerer at støde sammen med de retningslinjer, som staten har udstukket.

I en artikel på Forskerzonen i marts 2020 peger lektor i religionsvidenskab ved Aarhus Universitet, Jørn Borup, på, hvordan nogle mennesker er overbeviste om, at religionsdyrkelsen er meget mere beskyttende mod hvilken som helst virus end staternes forholdsregler (Borup 2020). Med troen på det religiøse ritual som indstiftet af Gud og derfor helligt følger hos nogen en overbevisning om, at ritualet ikke kan medvirke til noget ondt. Dette belyses også i flere af dette særnummers artikler. I den allerede omtalte artikel af Galal påpeges det, hvordan nogle af de koptisk-ortodokse præster i Egypten mener, at nadveren kurerer "alle sygdomme i menneskets kerne, krop og sjæl".

En lignende argumentation blev fremsat af religiøse ledere fra den russisk-ortodokse kirke. Det viser Mikhail Suslov i ar- 
tiklen "The Russian Orthodox Church and the Pandemic: Problems, Challenges, Responses”. Suslov, som er adjunkt i russisk ved Københavns Universitet, refererer til kirkerepræsentanters udtalelser i marts 2020, hvor de fastslår, at nadveren ikke kan medføre smitte, fordi der er tale om Jesu blod og legeme. Til gengæld kan de fysiske beholdere af brødet og vinen være smitteoverførende, og derfor stillede man krav om engangsbrug og jævnlig rengøring. Et lignende forsøg på at balancere mellem hensynet til de troende og efterlevelsen af myndighedernes krav betød, at religiøse ledere i stedet for at lukke kirkerne blandt andet henviste til et bibelsk eksempel, egyptiske Maria, med opfordringen til ikke at gå i kirke under de nuværende omstændigheder. Men opfordringen blev opfattet som en anbefaling snarere end en befaling, hvorfor mange troende ikke fulgte den.

At begrunde begrænsninger i religionsudøvelsen med religiøse analogier har været en udbredt praksis, ikke mindst blandt muslimer verden over. Det ser man i Sverige, som Sorgenfrei skriver om i den tidligere omtalte artikel, ligesom man finder eksempler herpå i Galals og Goris artikler. Både Gori og Galal viser derudover, at overnationale muslimske organisationer udstikker retningslinjer for, hvordan de rituelle forpligtelser kan udføres islamisk korrekt, selv om man f.eks. ikke kan mødes til fredagsbøn. Det fællesskabsorienterede aspekt af fredagsbønnen kan opretholdes ved enten at følge en imam virtuelt eller ved at bede derhjemme sammen som familie, som derved udgør et islamisk fællesskab.

Brugen af medier som platform for rituel praksis fik generelt vind i sejlene med covid-19. Det var også tilfældet i den protestantiske kirke i Tyskland, som Katharina Nötzold belyser i artiklen "Deafening silence of theologians vs. creative local parishes during the Corona pandemic? - A case study of the Evangelical Church in Germany (EKD)". Nötzold er ansvarshavende redaktør af Global Media Journal German Edition ved Freie Universitet i Berlin og har især fokus på den debat om kirkens rolle og relevans i det tyske samfund, der opstod som følge af pandemien. De protestantiske, katolske og ortodokse kirker kom allerede i marts 2020 med en fælles udtalelse med titlen "Assistance, trøst og håb”, og selv om denne udtalelse i stort omfang blev overset af medierne, afspejler titlen indholdet af den debat, der opstod om kirkens rolle. Den handlede i mindre grad om ritualer, som kirken gav forslag til, hvordan kunne løses. I stedet var fokus på kirkens rolle som omsorgsgiver i forhold til at hjælpe 
befolkningen igennem en krise.

En variant af dette mere sociale og psykologiske aspekt af den religiøse praksis kommer også til udtryk i artiklen "Da krisen ramte: Genforhandlingerne af amerikansk-jødiske samfundsværdier", skrevet af Maja Gildin Zuckerman, som er post. doc. ved Copenhagen Business School. Hun sætter fokus på de amerikanske jøder i USA, som har reageret på pandemien og de samtidige raceuroligheder i USA ved at organisere sociale (virtuelle) mødesteder, skabe moralske fællesskaber og proklamere stærke solidaritetserklæringer. Ifølge Zuckerman har covid-19-krisen gjort det klart for mange amerikanske jøder, at de har brug for dybe, pålidelige og autentiske etno-religiøse fællesskaber.

I forhold til de religiøse ritualer og rituel praksis har pandemien således været med til at skabe nye praksisser, men også fornyet opmærksomhed om religionens og det religiøse fællesskabs betydning. Nye interreligiøse og intrareligiøse tiltag er opstået for at skabe solidaritet og sammenhold, og disse har ført til nye virtuelle praksisser og har understreget eksistensen af troen på noget, der ligger udover rationelle og videnskabelige forklaringsrammer. Dermed har pandemien også bidraget til fornyet diskussion af sekularisme.

\section{Sekularisme og det postsekulære samfund}

I artiklen Danish Muslim during Covid-19: 'Relgion and pandecmics' in a postsecular society argumenterer Lene Kühle for, at der også i Danmark sker en sammenblanding af religiøse og sekulære agurmenter. Kühle er professor MSO i religionsvidenskab ved Aarhus Universitet og har undersøgt danske moskeers rolle under krisen på baggrund af deres offentlige kommunikation på sociale medier. Kühle trækker på Jürgen Habermas' forståelse af det postsekulære samfund som et sociologisk begreb, der analytisk er i stand til at rumme, at religion på trods af stigende sekularisering ikke forsvinder, og at religiøse stemmer fortsat indgår i samfundsdebatter (Habermas 2008, 2012). I artiklen viser Kühle, hvordan muslimer bakker op om myndighedernes retningslinjer og stræber efter at fremstå som den ansvarlige minoritet, ligesom Riexinger er inde på i sin artikel. Selv om den danske stats reaktion på pandemien klart er båret frem af sekulære argumenter, sker der således også en sammen- 
blanding af det religiøse og det sekulære. For eksempel viderebringer de muslimske organisationer de sekulære myndigheders budskaber, som om de var deres egne. Og fordi de teologiske reaktioner på pandemien i nogle tilfælde er blevet udarbejdet i samråd med muslimsk sundhedspersonale, fremstår sekulære og religiøse budskaber som sammenfaldende. De muslimske trossamfund i Danmark kan på den baggrund siges at tilpasse sig en sekulær samfundsorden.

Pandemiens betydning for forholdet mellem den religiøse og sekulære samfundsorden i den russiske kontekst fremstår, som analyseret af Suslov, noget mere kompleks. Hvor den russisk-ortodokse kirke under det sovjetiske styre var marginaliseret, har den i stigende grad indtaget en central samfundsrolle som moralsk og ideologisk autoritet, der har bidraget til en høj grad af symbiose og ideologisk overensstemmelse mellem den og det russiske regime. Alligevel har forholdet mellem de sekulære og religiøse myndigheder langt fra været harmonisk under pandemien, hvilket kirkens utilbøjelighed til at følge statens udstukne covid-19-retningslinjer illustrerer. Den fundamentalistiske fløj inden for kirken har lagt afstand til statens linje og udlagt den som en gentagelse af sovjettidens ateisme og undertrykkelse af religion. Således kan reaktionerne på pandemien i Rusland også sættes ind i diskussionen om det postsekulære samfund.

Et sidste eksempel, der også forbilledligt bidrager til diskussionen om sekularisme og postsekularisme, er Joshua Sabihs artikel om de ultraortodokse jøder i Israel. Sabih er dr.theol. (UN$\mathrm{CPH}$ ) og Diplôme post-doctoral en sciences historiques et philologiques (EPHE- Université Paris) og bidrager med artiklen "God is telling us something: Rabbi Amnon Yitzhak's Pesher and Socio-Political Pantheism of Coronavirus". Hans fokus er den ultraortodokse rabbiner, Amnon Yitzhaks (f. 1953) fortolkninger af og reaktioner på covid-19. Yitzhak er en fremtrædende prædikant og politiker, associeret med den ultraortodokse bevægelse i Israel, Mizrahi Haredi, og en af grundlæggerne af Ba alei Teshuva-bevægelsen i Israel. Israels vaccinepolitik er ifølge Yitzhak en måde at kontrollere og slavegøre befolkningen, og regeringens generelle håndtering tilsidesætter den hellige kraft, som om mennesket har magt over liv og død. Sabih argumenterer for, at Yitzhaks fortolkning ikke er en fuldstændig afvisning af videnskab og rationalitet, men snarere en afvisning af sekularisme og modernismes princip om, at "modern 
science is a practice which can only be fully understood on the basis of itself and performatively establishes the criterion of all that is true or false" (Habermas 2008, 210).

De ni artikler dokumenterer således, hvordan religion, religiøse institutioner og religiøse autoriteter bliver et aspekt $\mathrm{i}$ globale fortolkninger og håndteringer af covid-19. Det handler om langt mere end om smitterisiko ved forsamlinger i forbindelse med religiøse praksisser. Generelt viser artiklerne, at pandemien har åbnet op for forhandlinger af religionens rolle såvel som religionspraksis. Nye måder at praktisere ritualer og fællesskab er taget i brug, mens forholdet mellem stat og religiøse institutioner er blevet udfordret med både styrkede og svækkede relationer til følge. Samtidig er artiklernes casestudier eksempler på den analytiske relevans af det postsekulære perspektiv, hvor religiøse stemmer stadig spiller en samfundsmæssig rolle på ondt og godt.

Litteratur
Borup, Jørn. 2020. “Coronavirus sætter verdens religioner under pres". Videnskab.dk. https:// videnskab.dk/forskerzonen/kultursamfund/coronavirus-saetterverdens-religioner-under-pres. Habermas, Jürgen. 2008. 'Religion et Sphère Publique'. In Entre naturalisme et religion. Les défis de la démocratie. Vols 170-211. Paris: Gallimard.

Habermas, Jürgen. 2008. "Notes on post-secular society." In New perspectives quarterly 25 (4):17-29. Habermas, Jürgen. 2012. "A Postsecular World Society? On the Philosophical Significance of Postsecular Consciousness and the Multicultural World Society: An interview with Jürgen Habermas by Eduardo Mendieta." SSRC, http://blogs. ssrc.org/ tif/2010/02/03/apostsecular-worldsociety. 